\title{
Impact of Investors' Perception and Attitude towards Investment Decision in Mutual Funds at Velachery, Chennai
}

\author{
Dr.M. Kaveri and B. Bindu
}

\begin{abstract}
This study gets insight in to the impact of attitude and perception of investors on their investment decision in mutual funds. The study was descriptive and analytical in nature. The target population of this study consists of investors opted for investment in mutual fund at Velachery, Chennai. The sample size was 50 investors. Judgment sampling technique has been used to collect data from the investors who were experts in the field of investment and efficient in mutual fund. The data was collected by using primary and secondary data source. The questionnaire is segregated into four dimensions namely socio-economic factors of the investors, investors' perception towards investment in mutual funds, investors' attitude towards investment in mutual funds and investors' investment decision in mutual funds. The questionnaire was developed by using a nominal scale, ordinal scale and five point Likert scale. The secondary data used in the study was collected from related articles, journals, thesis, books, newspapers and internet, etc. In this study, the statistical measures namely reliability, frequencies, descriptive statistics, correlation and regression were used. The study found that there is a significant impact of attitude and perception of investors on their investment decision in mutual funds. Conclusions and suggestions are discussed.
\end{abstract}

Keywords--- Investors' Perception, Investors' Attitude, Investment Decision, Mutual Funds, Velachery, Chennai.

\section{INTRODUCTION}

$\mathrm{T}$ HE Indian mutual fund industry is growing rapidly and becoming most preferable investment for the small investors. As it offers an opportunity to invest in a diversified, professionally managed portfolio at a relatively low cost, mutual fund is considered as a significant mode of investment for majority of investors. The investors who seek to maximize their return on investment, mutual funds performs this task by joining their hands with 36 asset management companies including Indian public sector, private sector and joint ventures with foreign players. The mutual fund operation provides a reasonable protection to investors. Besides, presently all Schemes of mutual funds provide tax relief under

Dr.M. Kaveri, Assistant Professor, Department of Business Administration, Agurchand Manmull Jain College, Meenambakkam, Chennai. E-mail:maran78in@yahoo.co.in

B. Bindu, Assistant Professor, Department of Business Administration, Agurchand Manmull Jain College, Meenambakkam, Chennai. E-mail:bindukamalsingh@yahoo.in DOI:10.9756/IJRAS.10489
Section $80 \mathrm{~L}$ of the Income Tax Act and in addition, some schemes provide tax relief under Section 88 of the Income Tax Act lead to the growth of importance of mutual fund in the minds of the investors. Thus, mutual funds offers relatively key benefits to investors such as professional management, diversification, liquidity, flexibility, low transaction cost, transparency and well regulated and monitored by Securities and Exchange Board of India (SEBI), which endeavors to protect the interests of investors. The Mutual Funds usually invest their funds in equities, bonds, debentures; call money etc., depending on the objectives and terms of scheme floated by MF. Now days there are MF which even invests in gold or other asset classes to offer high returns to the investors. Therefore, the study undertaken to find out the attitude of investors' towards investment in mutual fund and their level of perception towards mutual fund at Veacherry, Chennai.

\section{Problem Definition}

Mutual funds have come forward as a much needed help to these investors. It is a special type of institutional device or an investment vehicle through which the investors pool their savings which are to be invested under the guidance of a team of experts in wide variety of portfolios of corporate securities in such a way, so as to minimize risk, while ensuring safety and steady return on investment. It forms an important part of the capital market, providing the benefits of a diversified portfolio and expert fund management to a large number, particularly small investors. Apart from these benefits, investment in mutual funds is a risky process for the investors. This may due to the underperformance of asset class, style drift and increases in cost due to high returns. Sometimes, the risk may also due to the change of efficient fund manager depending on whose decision you may incur profit. Thus, the study intended to find the factors influencing the investors to take investment decision in mutual funds. It also finds out the impact of attitude and perception of investors on their preferences and investment decision in mutual fund at Velachery, Chennai.

\section{OBJectives OF THE STUDY}

1) To examine the level of perception and attitude of investors towards investment in mutual funds.

2) To find out the factors influencing the investment decision of investors in mutual funds.

3) To identify the impact of attitude and perception of investors on their investment decision in mutual funds. 


\section{SignificAnce OF THE StUdy}

This study facilitate in knowing the level of attitude and perception of the investors' towards investment in mutual fund at Velachery, Chennai.

It also assist in finding out the factors influencing the investors to take investment decision in mutual funds and identifies the impact of investors' attitude and perception on their investment decision in mutual funds.

\section{LITERATURE REVIEW}

A. Investors' Perception towards Investment in Mutual Fund

Desigan et al (2006) conducted a study on women investors' perception towards investment and found that women investors', basically are indecisive in investing in mutual funds due to various reasons like lack of knowledge about the investment protection and their various investment procedures, market fluctuations, various risks associated with investment, assessment of investment and redressal of grievances regarding their various investment related problems. Savings is a habit specially embodied into women. Even in the past, when women mainly depended on their spouses' income, they used to save to meet emergencies as well as for future activities. In those days, women did not have any awareness about various investment outlets. But as time passed, the scenario has totally changed. Dr. Geeta Kesavaraja (2013) carried out the study with the aim to measure the-Customer Perception towards various types of Mutual Funds". It focuses its attention towards the possibilities of measuring the expectations and satisfaction level of more mutual fund products. It also aims to suggest techniques to improve the present level of perception. The study will help the firm in understanding the expectations, future needs and requirements and complaints of the consumers.

The study had been dedicated mainly towards the promotion of product or concept in the Chennai Market. The researcher used the Descriptive type of research design in her study. The researcher used the Primary data collection method in her study by framing a structured Questionnaire. The researcher went with convenient type of sampling method in her study.

The sample is taken as 204 by the researcher. For the purpose of Analysis and Interpretation the researcher used the following statistical tools namely Simple Percentage Analysis, Chi-Square Test, Karl Pearson's Correlation and One way Anova. Based on the Analysis and Interpretation the researcher arrived out with the major findings in her study and Suggestions are given in such a way so that the customers can attain the wealth maximization. Dhimen Jagdishbhai Jani, et al. (2012) focused on the consumer's perception towards mutual fund as an investment option in Valsad city from Gujarat. They revealed that Consumers perception were positive toward investment in mutual funds.

\section{B. Investors' Attitude towards Investment in Mutual Fund}

Lenard et., al. (2003) empirically investigated investor's attitudes toward mutual funds. The results indicate that the decision to switch funds within a fund family is affected by investor's attitude towards risk, current asset allocation, investment losses, investment mix, capital base of the fund age, initial fund performance, investment mix, fund and portfolio diversification.

The study reported that these factors are crucial to be considered before switching funds regardless of whether they invest in non-employer plans or in both employer and nonemployer plans.

Binod Kumar Singh (2011) conducted an empirical study of Indian investors and observed that most of the respondents do not have much awareness about the various function of mutual funds and they are bit confused regarding investment in mutual funds.

The study found that some demographic factors like gender, income and level of education have their significant impact over the attitude towards mutual funds. On the contrary age and occupation have not been found influencing the investor's attitude.

The study noticed that return potential and liquidity have been perceived to be most lucrative benefits of investment in mutual funds and the same are followed by flexibility, transparency and affordability.

\section{Investors' Investment Decision towards Mutual Fund}

Madhusudhan, V. Jambodekar (1996) conducted his study to size-up the direction of mutual funds in investors and to identify factors that influence mutual fund investment decision.

The study tells that open-ended scheme is most favored among other things and that income schemes and open-ended schemes are preferred over closed- ended and growth schemes.

News papers are used as information source, safety of principal amount and investor services are priority points for investing in mutual funds. Dr. Shantanu Mehta \& Charmi Shah (2012) have been undertaken a study to examine the preference of Investors for Indian Mutual Funds and its Performance Evaluation. A sample of 100 educated investors of Ahmedabad and Baroda city and the major findings reveal the major factors that influence buying behavior mutual funds investors, sources that investor rely more while making investment and preferable mode to invest in mutual funds market.

\section{Research Gap}

The above studies revealed that majority of the investors have positive attitude and perception towards mutual funds. They also have high preferences to invest in mutual funds to yield high return. But, there is no evident of impact of attitude and perception of investors towards investment decision in mutual funds. To fill this gap, the study has been undertaken to find out the relationship between perception, attitude and preferences of investors towards mutual fund in Velachery, Chennai. 


\section{Research Methodology}

The study is descriptive and analytical in nature. The target population of this study consists of investors opted for investment in mutual fund at Velachery, Chennai. The sample size is 50 investors.

Judgment sampling technique has been used to collect data from the investors who are experts in the field of investment and efficient in mutual fund. The data is collected by using primary and secondary data source. The questionnaire is segregated into four dimensions namely socio-economic factors of the investors, investors' perception towards investment in mutual funds, investors' attitude towards investment in mutual funds and investors' investment decision in mutual funds.

The questionnaire is developed by using a nominal scale, ordinal scale and five point Likert scale. The secondary data used in the study have been collected from related articles, journals, thesis, books, newspapers and internet, etc. In this study, the statistical measures namely reliability, frequencies, descriptive statistics, correlation and regression are used.

\section{HYPOTHESES DEVELOPMENT}

Based on the objectives of the study, the following hypotheses are developed.

$\mathrm{H}_{11}$ : There is a significant relationship between investors' perception and attitude towards investment in mutual funds and their investment decision in mutual funds.

$\mathrm{H}_{12}$ : There is a significant association between mutual fund companies and investors' perception, attitude and investment decision in mutual funds.

$\mathrm{H}_{13}$ : There is a significant impact of investors' perception and attitude towards investment in mutual funds on their investment decision in mutual funds.

\section{DATA ANALYSIS AND INTERPRETATION}

\section{A. Cronbach's Alpha Reliability Test}

It is used to examine the internal consistency of variables in the construct. Cornbach's Alpha states that reliability less than 0.60 are considered to be poor, while those in the 0.70 range are acceptable and those over 0.80 are considered good (George, D., and Mallery, P., 2003 and Kline, P., 2000).

Table 1: Cronbach’s Alpha Reliability Test

\begin{tabular}{|l|l|l|l|}
\hline $\begin{array}{c}\text { Sl. } \\
\text { No. }\end{array}$ & \multicolumn{1}{|c|}{ Scale } & \multicolumn{1}{|c|}{$\begin{array}{c}\text { No. of } \\
\text { Items }\end{array}$} & \multicolumn{1}{|c|}{$\begin{array}{c}\text { Cronbach's } \\
\text { Alpha }(\alpha)\end{array}$} \\
\hline 1. & $\begin{array}{l}\text { Investors' Perception towards } \\
\text { Investment in Mutual Funds. }\end{array}$ & 5 & 0.901 \\
\hline 2. & $\begin{array}{l}\text { Investors' Attitude towards } \\
\text { Investment in Mutual Funds. }\end{array}$ & 5 & 0.916 \\
\hline 3. & $\begin{array}{l}\text { Investors' Investment Decision in } \\
\text { Mutual Funds. }\end{array}$ & 5 & 0.945 \\
\hline
\end{tabular}

[Source: Primary data]

From the above table, it is learnt that Cronbach's Alpha reliability for all the factors was above $80 \%$ which means that the variables produce consistent results if measurements are made repeatedly.

\section{B. Frequencies}

Table 2: Socio-Economic Status of the Investors

\begin{tabular}{|c|c|c|c|}
\hline $\begin{array}{l}\text { Sl. } \\
\text { No. }\end{array}$ & Particulars & Frequency & Percentage \\
\hline 1. & $\begin{array}{l}\text { Gender } \\
\text { Male } \\
\text { Female } \\
\text { Total }\end{array}$ & $\begin{array}{l}36 \\
14 \\
50 \\
\end{array}$ & $\begin{array}{l}72 \\
28 \\
100 \\
\end{array}$ \\
\hline 2. & $\begin{array}{l}\text { Age } \\
25-35 \text { Yrs } \\
35-45 \text { Yrs } \\
45-55 \text { Yrs } \\
56 \text { and above } \\
\text { Total }\end{array}$ & $\begin{array}{l}12 \\
20 \\
10 \\
8 \\
50 \\
\end{array}$ & $\begin{array}{l}24 \\
40 \\
20 \\
16 \\
100 \\
\end{array}$ \\
\hline 3. & $\begin{array}{l}\text { Occupation of the Respondent } \\
\text { Private } \\
\text { Public } \\
\text { Business } \\
\text { Profession } \\
\text { Retired } \\
\text { Total }\end{array}$ & $\begin{array}{l}18 \\
10 \\
12 \\
6 \\
4 \\
50\end{array}$ & $\begin{array}{l}36 \\
20 \\
24 \\
12 \\
8 \\
100\end{array}$ \\
\hline 4. & $\begin{array}{l}\text { Criteria Considered for Investment in } \\
\text { Mutual Fund } \\
\text { Safety } \\
\text { Return } \\
\text { Liquidity } \\
\text { Convenience } \\
\text { Tax Planning } \\
\text { Total }\end{array}$ & $\begin{array}{l}16 \\
11 \\
6 \\
5 \\
12 \\
50\end{array}$ & $\begin{array}{l}32 \\
22 \\
12 \\
10 \\
24 \\
100\end{array}$ \\
\hline 5. & $\begin{array}{l}\text { Expectations from Mutual Fund } \\
\text { Advisory } \\
\text { Fair, genuine and right advice } \\
\text { Speed of transaction } \\
\text { Reputation } \\
\text { reliability } \\
\text { Investor facilitation } \\
\text { Easy procedure } \\
\text { Total }\end{array}$ & $\begin{array}{l}14 \\
13 \\
10 \\
5 \\
3 \\
5 \\
50\end{array}$ & $\begin{array}{l}28 \\
26 \\
20 \\
10 \\
6 \\
10 \\
100\end{array}$ \\
\hline 6. & $\begin{array}{l}\text { Companies Preferred for Investment in } \\
\text { Mutual Fund } \\
\text { SBI } \\
\text { UTI } \\
\text { Kotak } \\
\text { ICICI } \\
\text { HDFC } \\
\text { Sundaram } \\
\text { Birla Sun Life } \\
\text { Total }\end{array}$ & $\begin{array}{l}11 \\
12 \\
8 \\
7 \\
5 \\
4 \\
3 \\
50\end{array}$ & $\begin{array}{l}22 \\
24 \\
16 \\
14 \\
10 \\
8 \\
6 \\
100\end{array}$ \\
\hline 7. & $\begin{array}{l}\text { Schemes Preferred for Investment } \\
\text { Growth Schemes } \\
\text { Sector-specific schemes } \\
\text { Balanced Schemes } \\
\text { Tax Saving Schemes } \\
\text { Total }\end{array}$ & $\begin{array}{l}20 \\
6 \\
9 \\
15 \\
50 \\
\end{array}$ & $\begin{array}{c}40 \\
12 \\
18 \\
30 \\
100\end{array}$ \\
\hline
\end{tabular}

[Source: Primary data]

From the above table, it can be inferred that $72 \%$ of the investors are male, $40 \%$ of the investors are belong to the age group between $35-45$ years, $36 \%$ of the investors are working in private sector companies, $32 \%$ of the investors consider safety as a major reason to prefer mutual funds for investment, $28 \%$ of the investors expect fair, genuine and right advice from the mutual fund advisory, $24 \%$ of the respondents prefer UTI company to invest in mutual fund and $40 \%$ of them prefer to invest in growth scheme mutual funds.

\section{Descriptive Statistics}

In order to find out the investors' level of perception, attitude and their investment decision in mutual funds, descriptive statistics is applied. 
Table 3: Mean and Standard Deviation

\begin{tabular}{|l|l|l|l|}
\hline $\begin{array}{l}\text { Sl. } \\
\text { No. }\end{array}$ & Scale & Mean & $\begin{array}{l}\text { Standard } \\
\text { Deviation }\end{array}$ \\
\hline 1. & $\begin{array}{l}\text { Investors' Perception towards } \\
\text { Investment in Mutual Funds. }\end{array}$ & 3.68 & 0.914 \\
\hline 2. & $\begin{array}{l}\text { Investors' Attitude towards Investment } \\
\text { in Mutual Funds. }\end{array}$ & 3.41 & 0.869 \\
\hline 3. & $\begin{array}{l}\text { Investors' Investment Decision in } \\
\text { Mutual Funds. }\end{array}$ & 3.53 & 0.893 \\
\hline
\end{tabular}

[Source: Primary data]

From the above table, the mean value of investors' level of perception, attitude and their investment decision in mutual funds are above 3.00; which means that the investors have positive perception, attitude towards investment in mutual funds. In addition, they have taken optimistic decision on invest in mutual fund.

\section{Correlation}

In order to find the significant relationship between investors' perception and attitude towards investment in mutual funds and their investment decision in mutual funds, correlation is used.

$\mathrm{H}_{01}$ : There is no significant relationship between investors' perception and attitude towards investment in mutual funds and their investment decision in mutual funds.

$\mathrm{H}_{11}$ : There is a significant relationship between investors' perception and attitude towards investment in mutual funds and their investment decision in mutual funds.

Table 4: Investors’ Perception, Attitude and Investment Decision in Mutual Funds

\begin{tabular}{|c|c|c|c|}
\hline Variables & $\begin{array}{c}\text { Investors' } \\
\text { Perception } \\
\text { towards } \\
\text { Investment in } \\
\text { Mutual Funds }\end{array}$ & $\begin{array}{c}\text { Investors' } \\
\text { Attitude towards } \\
\text { Investment in } \\
\text { Mutual Funds }\end{array}$ & $\begin{array}{c}\text { Investors' } \\
\text { Investment } \\
\text { Decision in } \\
\text { Mutual Funds }\end{array}$ \\
\hline $\begin{array}{l}\text { Investors' } \\
\text { Perception } \\
\text { towards } \\
\text { Investment in } \\
\text { Mutual Funds }\end{array}$ & 1 & $0.951^{* *}$ & $0.932^{* *}$ \\
\hline $\begin{array}{l}\text { Investors' } \\
\text { Attitude towards } \\
\text { Investment in } \\
\text { Mutual Funds }\end{array}$ & $0.951^{* *}$ & 1 & $0.968^{* *}$ \\
\hline $\begin{array}{l}\text { Investors' } \\
\text { Investment } \\
\text { Decision in } \\
\text { Mutual Funds }\end{array}$ & $0.932^{* *}$ & $0.968^{* *}$ & 1 \\
\hline
\end{tabular}

[Source: Primary data]

Note: ** Denotes correlation is significant at $1 \%$ level.

Since the $\mathrm{P}$ value is less than 0.01 , the null hypothesis is rejected at 1 percent level of significance. Hence it is concluded that the independent factors namely investors' perception and attitude towards investment in mutual funds have a positive and strong relationship with their investment decision in mutual funds. This implies as the investors' perception and attitude towards investment in mutual funds increases, the level of investment decision in mutual funds also increases. It is also clear from the above table that maximum correlation exists between investors' attitude towards investment in mutual funds and investment decision in mutual funds (0.968), followed by investors' perception towards investment in mutual funds and investors' attitude towards investment in mutual funds (0.951). From the above table, it is also evident that investors' perception and attitude towards investment in mutual funds are pair wise positively significant at 1 percent level (0.932).

\section{E. Correspondence Analysis}

In order to find the significant association between mutual fund companies and investors' investment decision in mutual funds, correspondence analysis is used.

$\mathrm{H}_{02}$ : There is no significant association between mutual fund companies and investors' investment decision in mutual funds.

$\mathrm{H}_{12}$ : There is no significant association between mutual fund companies and investors' investment decision in mutual funds.

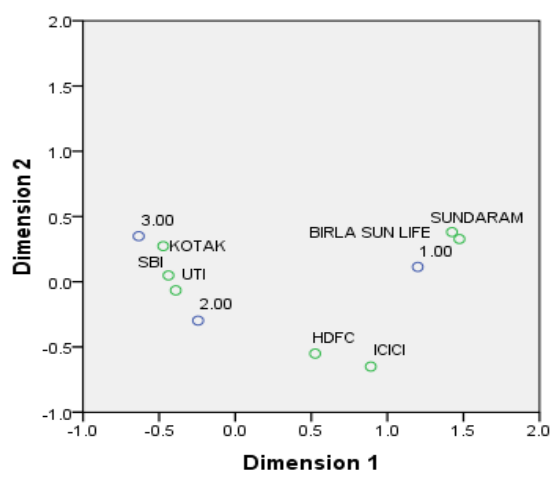

OINUESTMENT DECISION IN

Figure 1: Mutual Fund Companies and Investors' Investment Decision in Mutual Funds

The above figure illustrates the association between mutual fund companies and investors' investment decision in mutual funds. The investors' preferred to invest in SBI, UTI and Kotak mutual fund companies have high level of investment decision in mutual funds. The investors' preferred to invest in HDFC and ICICI mutual fund companies have moderate level of investment decision in mutual funds and the investors' preferred to invest in Sundaram and Birla sun life mutual fund companies have low level of investment decision in mutual funds.

\section{F. Regression}

$\mathrm{H}_{03}$ : There is no significant impact of investors' perception and attitude towards investment in mutual funds on their investment decision in mutual funds.

$\mathrm{H}_{13}$ : There is a significant impact of investors' perception and attitude towards investment in mutual funds on their investment decision in mutual funds.

Table 5.a: Predictor Variables of Multiple Regression Analysis

\begin{tabular}{|l|c|c|c|c|c|}
\hline $\begin{array}{c}\text { Multiple } \\
R \text { value }\end{array}$ & $\begin{array}{c}R \\
\text { Square } \\
\text { value }\end{array}$ & $\begin{array}{c}\text { Adjusted } \\
R^{2} \text { value }\end{array}$ & Fvalue & $\begin{array}{c}\text { Standard } \\
\text { Error }\end{array}$ & $P$ value \\
\hline 0.904 & 0.817 & 0.816 & 1009.625 & 1.92119 & $<0.001^{* *}$ \\
\hline
\end{tabular}

[Source: Primary data]

Note: $* *$ Denotes correlation is significant at $1 \%$ level 
Table 5.b: Coefficients between Investors' Perception, Attitude and Investment Decision in Mutual Funds

\begin{tabular}{|l|c|c|c|l|l|}
\hline \multicolumn{1}{|c|}{ Variables } & USC & SE & SC & t value & P value \\
\hline (Constant) & 1.143 & 0.434 & & 2.636 & $0.009^{* *}$ \\
\hline $\begin{array}{l}\text { Investors' Perception } \\
\text { towards Investment in } \\
\text { Mutual Funds }\end{array}$ & 0.616 & 0.037 & 0.612 & 16.661 & $<0.001^{* *}$ \\
\hline $\begin{array}{l}\text { Investors' Attitude towards } \\
\text { Investment in Mutual Funds }\end{array}$ & 0.415 & 0.047 & 0.327 & 8.891 & $<0.001^{* *}$ \\
\hline
\end{tabular}

[Source: Primary data]

Note: ${ }^{* *}$ Denotes significant at $1 \%$ level.

Dependent Variable $(\mathrm{Y})=$ Investors' Investment Decision in Mutual Funds

Independent/Predictor Variable=Investors' Perception towards Investment in Mutual Funds $\left(\mathrm{X}_{1}\right)$ and Investors' Attitude towards Investment in Mutual Funds $\left(\mathrm{X}_{2}\right)$

The above table revealed that investors' investment decision in mutual funds can be predicted at $\mathrm{R}^{2}=0.817$. In this model, the value of $\mathrm{R}^{2}$ denotes that $81.7 \%$ of the observed variability in investors' investment decision in mutual funds can be significantly explained by their perception and attitude towards investment in mutual funds. The remaining $18.3 \%$ is not explained which means that the rest $18.3 \%$ of the variation of investors' investment decision in mutual funds is related to other variables which are not depicted in this model. Since the $\mathrm{p}$ value is less than 0.01 , the null hypothesis is rejected at 1 percent level of significance. Hence the linear combination of investors' perception and attitude towards investment in mutual funds is significantly related to their investment decision in mutual funds ( $\mathrm{F}=1009.625$ and $\mathrm{P}=<0.001^{* *}$ ).

The Ordinary Least Squares (OLS) equation for predicting investors' investment decision in mutual funds is:

Investors' Investment Decision in Mutual Funds $(\mathrm{Y})=$ $0.616 \mathrm{X}_{1}+0.415 \mathrm{X}_{2}+\mathrm{e}$

The coefficient of $\mathrm{X} 1$ is 0.616 which represents the direct relationship between investors' perception towards investment in mutual funds and their investment decision in mutual funds. The estimated positive sign indicates that for each additional unit of investors' perception towards investment in mutual funds, there is a 0.616 unit increase in their investment decision in mutual funds and it is significant at $1 \%$ level.

The coefficient of $\mathrm{X} 1$ is 0.415 which represents the direct relationship between investors' attitude towards investment in mutual funds and their investment decision in mutual funds. The estimated positive sign indicates that for each additional unit of investors' attitude towards investment in mutual funds, there is a 0.415 unit increase in their investment decision in mutual funds and it is significant at $1 \%$ level.

\section{FINDINGS}

Based on the frequencies, the study found that majority of the investors consider safety as a major reason to prefer mutual funds for investment and they expect fair, genuine and right advice from the mutual fund advisory. It addition, majority of the respondents prefer UTI company to invest in mutual fund and they prefer to invest in growth scheme mutual funds. From the mean and standard deviation, it is clear that the investors have positive perception, attitude towards investment in mutual funds and they have taken optimistic decision on invest in mutual fund. From the Correlation matrix, it is clear that there is a positive and significant relationship between investors' perception and attitude towards investment in mutual funds and their investment decision in mutual funds. From the correspondence analysis, it has been proven that the investors' preferred to invest in SBI, UTI and Kotak mutual fund companies have high level of investment decision in mutual funds, followed by moderate level towards HDFC and ICICI mutual fund companies and low level in Sundaram and Birla sun life mutual fund companies. From the Regression model, it has been found that there is a significant impact of investors' perception and attitude towards investment in mutual funds on their investment decision in mutual funds.

\section{Suggestions}

Indian mutual funds play a significant role in bringing stability into the financial system and efficiency in resource allocation. Mutual Funds utilize the public money of investors in a proper way and distribute reasonable returns to them. The fund managers should be efficient in portfolio allocation under risk and returns proposition. Their selection of funds should provide proper security to the investors. The fund advisory should act in a fair and genuine manner in providing advice to the investors towards their investment in different schemes. Based on the analysis, majority of the investors like to prefer SBI, UTI and Kotak for their investment. Therefore, it is mandatory for the other companies to improve their mutual fund schemes by combining various investment avenues to offer maximum return to their investors.

\section{CONCLUSION}

Today, investor' level of perception, attitude towards investment in mutual funds is increasing and they have taken optimistic decision on invest in mutual fund. This shows the growth status of mutual funds in India. This study has proven that there is a significant impact of investors' perception and attitude towards investment in mutual funds on their investment decision in mutual funds. Therefore, it is mandatory for the investment companies to focus on efficient and effective allocation of portfolio in different schemes to enhance their attitude and perception towards investment in mutual fund. It is also noted that the investors like to invest in growth schemes and therefore, the investment companies should concentrate on portfolio allocation and management in growth schemes.

\section{LIMITATIONS OF THE STUDY}

1) The study is limited to investors' perception and attitude towards investment decision in mutual funds at Velachery, Chennai.

2) The number of respondents is limited to 50.

\section{REFERENCES}

[1] B.K. Singh, "A study on investors' attitude towards mutual funds as an investment option”, Journal of Asian Business Strategy, Vol. 1, No. 2, 2011.

[2] A. Bryman, "Social research methods”, Oxford university press, 2015. 
[3] L.J. Cronbach, "Coefficient alpha and the internal structure of test", Psychometrika, Vol. 16, No. 3, Pp. 297-334, 1951.

[4] C.G. Desigan, S. Kalaiselvi and L. Anusuya, "Women Investors' Perception Towards Investment-An Empirical Study”, Indian Journal of Marketing, Vol. 36, No. 4, 2006.

[5] D.J. Jani, B.A. Patel and R.V. Jain, "Consumer’s Perception towards Mutual Funds as an Investment Option Specially Focused on Valsad City Located in Gujarat”, International Journal of Business Management \& Research (IJBMR), Vol. 2, No. 4, Pp. 59-66, 2012.

[6] Dr.G. Kesavaraja, "Study on Customer Perception towards Various Types of Mutual Funds in Chennai”, Asia Pacific Journal of Research, 2013.

[7] S. Mehta and C.H.A.R.M.I. Shah, "Preference of Investors for Indian mutual funds and its performance evaluation”, Pacific Business Review International, Vol. 5, No. 3, Pp. 62-76, 2012

[8] G. Argyrous, "Statistics for research: with a guide to SPSS", Sage Publications, 2011.

[9] M.J. Lenard, S.H. Akhter and P. Alamc, "Mapping Mutual Fund Investor Characteristics And Modelling Switching Behaviour", Financial Services Review, Vol. 12, No. 1, Pp. 39-59, 2003.

[10] M.V. Jambodekar, "Marketing strategies of mutual funds-Current practices and future directions", 1996.

[11] R. Nargundkar, "Marketing Research", McGrawhill Education, $3^{\text {rd }}$ Edition, 2008. 